\title{
The Function of Sn(II)-Apatite as a Tc Immobilizing Agent
}

R. Matthew Asmussen ${ }^{1}$, James J. Neeway ${ }^{I}$, Amanda R. Lawter ${ }^{I}$, Tatiana G Levitskaia ${ }^{1}$, Wayne W. Lukens ${ }^{2}$, Nikolla P. Qafoku ${ }^{1}$

${ }^{1}$ Energy and Environment Directorate, Pacific Northwest National Laboratory, 902 Battelle Blvd, Richland, Washington, 99352

${ }^{2}$ Chemical Sciences Division, Lawrence Berkeley National Laboratory, Berkeley, California, 94720

KEYWORDS : technetium, nuclear waste, $\mathrm{x}$-ray absorption spectroscopy, waste forms, Hanford Corresponding Author E-mail: matthew.asmussen@pnnl.gov 
ABSTRACT At the U.S. Department of Energy Hanford Site, Tc-99 is a component of lowactivity waste (LAW) fractions of the nuclear tank waste and removal of Tc from LAW streams would greatly benefit the site remediation process. In this study, we investigated the removal of $\mathrm{Tc}(\mathrm{VII})$, as pertechnetate, from deionized water (DIW) and a LAW simulant through batch sorption testing and solid phase characterization using tin (II) apatite (Sn-A) and $\mathrm{SnCl}_{2}$. Sn-A showed higher levels of Tc removal from both DIW and LAW simulant. Scanning electron microscopy/energy dispersive X-ray spectroscopy (SEM/XEDS) and X-ray absorption spectroscopy (XAS) of reacted Sn-A in DIW showed that TcO4- is reduced to Tc(IV) on the SnA surface. The performance of Sn-A in the LAW simulant was lowered due to a combined effect of the high alkalinity, which lead to an increased dissolution of Sn from the Sn-A, and a preference for the reduction of $\mathrm{Cr}(\mathrm{VI})$. 
1. INTRODUCTION Technetium-99 $\left(\mathrm{Tc}, \mathrm{t}_{1 / 2}=213000 \mathrm{a}\right)$ is a radioactive contaminant of high concern at many global nuclear waste storage sites, [1-4] as evidenced by the Tc remediation and cleanup efforts at the U.S. Department of Energy (DOE) Hanford Site.[5] Current plans call for the low activity waste (LAW) stored in tanks at the Hanford site, which contain Tc, to be solidified through vitrification at the Hanford Tank Waste Treatment and Immobilization Plant (WTP). However, there are limitations for the incorporation of Tc in mid- to high-temperature immobilization processes due to the volatility of Tc compounds.[6] Additionally, Tc has high environmental mobility in aerobic environments when it exists in the anionic Tc (VII) form, pertechnetate $\left(\mathrm{TcO}_{4}{ }^{-}\right)$.[7] Thus, providing a suitable disposal matrix with a high chemical durability for wastes that contain and stabilize Tc is imperative.

Treatment of waste streams to selectively remove $\mathrm{Tc}$ and other redox active species is a potential process that can aid in Tc management. Two removal pathways for $\mathrm{TcO}_{4}{ }^{-}$from aqueous environments are prevalent: (1) ion exchange, and (2) reduction of $\mathrm{Tc}(\mathrm{VII})$, as $\mathrm{TcO}_{4}^{-}$, to a highly insoluble $\mathrm{Tc}(\mathrm{IV})$ species, such as $\mathrm{TcO}_{2} \cdot \mathrm{xH}_{2} \mathrm{O}\left(\mathrm{K}_{\mathrm{sp}}=10^{-32}\right) \cdot[8,9]$ The separated $\mathrm{Tc}$ can then be immobilized in a waste form where it can be safely disposed. Several candidate materials for the uptake and immobilization of $\mathrm{TcO}_{4}^{-}$from aqueous solutions have been previously studied, including minerals, organic compounds, inorganic compounds and redox active materials, with varying levels of success.[10-13] However, many of these studies were performed in deionized water (DIW), or in solutions with simple compositions. A successful candidate material for Tc immobilization through a redox process needs to have two ideal characteristics: high removal capacity/selectivity for $\mathrm{TcO}_{4}{ }^{-}$and sufficient reductive potential to convert it to $\mathrm{Tc}(\mathrm{IV})$. Materials with these traits would also need to demonstrate low rates of $\mathrm{Tc}$ desorption, compatibility with a final waste form, low cost and long term stability.[11] 
One material that has shown potential for Tc removal in simulated groundwater is tin (II) apatite (Sn-A), ideally $\mathrm{Sn}_{5}\left(\mathrm{PO}_{4}\right)_{3}(\mathrm{~F}, \mathrm{Cl}, \mathrm{OH})$. [14, 15] The reductive capability of Sn-A arises from the presence of $\mathrm{Sn}(\mathrm{II})$, which has a favourable reduction potential for $\mathrm{Sn}(\mathrm{IV}) / \mathrm{Sn}$ (II) of $0.384 \mathrm{~V}[16]$ and can reduce $\mathrm{Tc}(\mathrm{VII})$ to $\mathrm{Tc}(\mathrm{IV})$. The $\mathrm{Tc}(\mathrm{VII}) / \mathrm{Tc}(\mathrm{IV})$ standard reduction potential is $0.738 \mathrm{~V}$.[15] The reduction of $\mathrm{TcO}_{4}{ }^{-}$by $\mathrm{Sn}$ (II) has been used in chemical syntheses in pharmaceutical development.[17] The second component, apatite (calcium phosphate), has also been reported to have an affinity for the sorption of Tc species in artificial groundwater,[18] and also in studies of bone, as the supporting anions in the apatite could be supplanted by $\mathrm{TcO}_{4}^{-}$.[19, 20] In addition, anionic selenium species $\left(\mathrm{SeO}_{4}{ }^{2-}\right)$ similar to pertechnetate have previously been reported to adsorb to apatite structures in a substitution mechanism with phosphate.[21] However, these processes have not been tested in high alkaline environments such as LAW. Though it is understood that both the $\mathrm{Sn}(\mathrm{II})$ and supporting apatite structure may play a role in the removal of Tc by Sn-A, the contribution of each component has yet to be reported in detail.

In this study we investigate whether Sn-A exhibits high and selective affinity for Tc and can function as a material for removal of aqueous $\mathrm{TcO}_{4}{ }^{-}$from a LAW simulant and DIW. Novel work to elucidate the mechanism of removal of Tc by Sn-A will also be presented based on results from solid-state characterization techniques. In addition, $\mathrm{SnCl}_{2}$ was tested for comparison as it is fully soluble in water and supplies a source of the $\mathrm{Sn}(\mathrm{II})$ reductant in solution without a solid interface present. The testing involved batch sorption experiments using $\mathrm{Sn}-\mathrm{A}$ and $\mathrm{SnCl}_{2}$ for Tc sequestration from solutions with high ionic strength that contain competing redox sensitive constituents found in LAW. This work represents a novel venture to investigate the nature of the Sn-A before, during, and after contact with Tc-bearing solutions. The results of this study are relevant to treatment of liquid nuclear wastes and long-term immobilization of Tc, both 
necessary advancements required for the sustained use of atomic energy and safe disposal of nuclear wastes.

2. MATERIALS AND METHODS Two materials were utilized in this work: tin (II) Apatite (Sn-A), $\left(\mathrm{Sn}_{5}\left(\mathrm{PO}_{4}\right)_{3}(\mathrm{X})\right)$ where $\mathrm{X}$ is a supporting anion $\left.(\mathrm{Cl}, \mathrm{F}, \mathrm{OH})\right]$ and $\mathrm{SnCl}_{2}$ (Sigma Aldrich). The Sn-A was prepared by an outside laboratory following a previously reported method.[22, 23] Sn-A prepared with this synthetic method has been reported to be comprised of an apatite $\left(\mathrm{Ca}_{\mathrm{x}}\left(\mathrm{PO}_{4}\right)_{\mathrm{y}}(\mathrm{X})\right)$ structure with partial substitution of $\mathrm{Ca}(\mathrm{II})$ by $\mathrm{Sn}(\mathrm{II})$ in the lattice.[23] The exact chemical content of the supplied materials was determined using microwave digestion (per U.S. EPA Method 3051A, Revision 1 2007) and the moisture content was determined gravimetrically (per ASTM D2216). Further details can be found in the supplemental information. The Sn-A had a moisture content of $66.78 \mathrm{wt} \%$ and the $\mathrm{SnCl}_{2}$ had a moisture content of $0.51 \mathrm{wt} \%$. From microwave digestion and subsequent analysis with inductively coupled plasma optical emission spectroscopy (ICP-OES), the Sn-A was found to contain $25.0 \mathrm{wt} \% \mathrm{Ca}, 14.4 \mathrm{wt} \% \mathrm{P}$ and $23.5 \mathrm{wt} \% \mathrm{Sn}$, with the remainder comprised of O $(29.8 \mathrm{wt} \% \mathrm{O}$ if all assumed to be with $\mathrm{P}$ as $\mathrm{PO}_{4}$ ) and supporting anions. Sn-A has previously been reported to be an amorphous pattern with only a weak crystalline hydroxyapatite peak appearing, see Appendix B of Qafoku et al. [22, 24]Without supporting anion identification, the exact formula of Sn-A cannot be determined. The likely formula for the $\mathrm{Sn}-\mathrm{A}$ is $\mathrm{Ca}_{\mathrm{x}-\mathrm{y}} \mathrm{Sn}_{\mathrm{y}}\left(\mathrm{PO}_{4}\right)_{\mathrm{x}}(\mathrm{X})$, where $\mathrm{X}$ is the supporting anion. $\mathrm{SnCl}_{2}$ was selected as a source of $\mathrm{Sn}(\mathrm{II})$ reductant in solution without a solid interface present. The reduction capacity of $\mathrm{Sn}$-A was measured using the $\mathrm{Ce}(\mathrm{IV})$ method, details of which can be found in a recent work by Um et al.[25]

The performance of the materials was investigated in DIW Millipore ${ }^{\circledR}$ water $(18.2 \mathrm{M} \Omega$ $\mathrm{cm}$ ) and a LAW simulant (7.8 M Na Average LAW simulant,[26] referred to as LAW simulant 
from here on). The composition of the LAW simulant solution was based on the Hanford Tank Waste Operations Simulator (HTWOS) model[27] and is presented in Table 1. The LAW simulant was prepared by adding half of the target volume of DIW (500 mL for a 1L final batch) to an empty beaker or flask and then adding a stir bar. The compounds were then added in the order listed in Table 1. Each compound was fully dissolved with stirring before the addition of the next compound. If dissolution did not immediately occur, the solution was heated to $70{ }^{\circ} \mathrm{C}$. Following the addition of the final compound, DIW was added to meet the targeted total volume. It must be noted that undissolved solids remained following completion of the LAW simulant preparation. These solids lead to some variance in the composition of the simulant, hence the nomenclature of a 7.8 $\mathrm{M}$ Na average simulant.

Two additional solutions based on the LAW simulant were used in this work. For experiments conducted in the absence of $\mathrm{Cr}$, the LAW simulant was prepared as listed in Table 1, omitting the $\mathrm{Na}_{2} \mathrm{Cr}_{2} \mathrm{O}_{7} \cdot 2 \mathrm{H}_{2} \mathrm{O}$. This solution is named "LAW simulant No Cr". A simplified form of the LAW simulant was also used to investigate the effects of the minor constituents of the LAW simulant in the batch tests. This solution contained only two of the major components of the LAW simulant: $\mathrm{NaNO}_{3}(1.04 \mathrm{~mol} / \mathrm{L})$ and $\mathrm{NaOH}(4.34 \mathrm{~mol} / \mathrm{L})$. The $\mathrm{NaNO}_{3}$ and $\mathrm{NaOH}$ were added to DIW in the amounts listed in Table 1 and this solution is

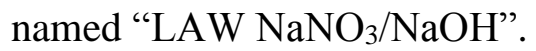

The effectiveness of the $\mathrm{Sn}-\mathrm{A}$ and $\mathrm{SnCl}_{2}$ was investigated with duplicate batch sorption experiments. The data presented is the average of the duplicate measurements and error bars are the standard deviation of the mean. The experiments were contained within $250 \mathrm{~mL}$ polytetrafluoroethylene bottles at room temperature, $\sim 22^{\circ} \mathrm{C}$, in an anaerobic chamber containing a mixed $\mathrm{H}_{2} / \mathrm{N}_{2}$ atmosphere with $\mathrm{O}_{2}$ levels below $5 \mathrm{ppm}$. One gram of material was 
added to $100 \mathrm{~mL}$ solution for the batch experiments. Additional tests varied the solid : solution ratio. Following addition of the DIW or LAW simulant to the bottle, the solutions were equilibrated in the anaerobic chamber overnight, then spiked with a concentrated stock solution of $\mathrm{NH}_{4} \mathrm{TcO}_{4}$ in water $(>10000 \mathrm{ppm})$ to achieve Tc concentrations of $1 \times, 5 \times$ and $10 \times$ the level predicted by HTWOS for a 7.8 M Na average LAW (5.6 ppm). Initial blank Tc concentrations were measured from identical solutions without any $\mathrm{Sn}-\mathrm{A}$ or $\mathrm{SnCl}_{2}$ added. In experiments designed to observe the release of elements $(\mathrm{Ca}, \mathrm{P}, \mathrm{Sn})$ from the $\mathrm{Sn}-\mathrm{A}$, the solutions were not spiked with Tc. Periodic sampling was performed by acquisition of a $2 \mathrm{~mL}$ aliquot of solution from the test vessels, which was immediately filtered $(0.2 \mu \mathrm{m})$. The samples were then acidified with $20 \mu \mathrm{L}$ of $70 \% \mathrm{HNO}_{3}$ for Tc analysis by inductively coupled plasma mass spectroscopy (ICP-MS). ICP-MS samples from DIW experiments were diluted 20× for analyses and in samples from the LAW simulant a 5000× dilution was used. The matrix determined detection limit for Tc resulting from these dilutions was $0.082 \mathrm{ppb}$ for the $20 \times$ and $20.5 \mathrm{ppb}$ for the $5000 \times$.

Following contact experiments, any remaining solid phase in the reaction bottle was removed and imaged by scanning electron microscopy (SEM) using a FEI Helios 600 NanoLab focused ion beam (FIB)/SEM. Images were collected at an accelerating voltage of $20 \mathrm{keV}$ and elemental levels determined with energy dispersive x-ray spectroscopy (XEDS) at an accelerating voltage of $10 \mathrm{keV}$. Further characterization was performed using X-ray absorption spectroscopy (XAS). Details on the XAS measurements are included in the supplemental information.

\section{RESULTS}

\subsection{Tc Removal Performance in DIW}


Figure 1(a) displays the \% Tc removal values for the $\mathrm{Sn}-\mathrm{A}$ and $\mathrm{SnCl}_{2}$ measured in DIW at three levels of initial Tc concentration ( $5 \mathrm{ppm}, 28 \mathrm{ppm}, 56 \mathrm{ppm})$. It is clear from the plot that the $\mathrm{Sn}-\mathrm{A}$ outperformed the $\mathrm{SnCl}_{2}$ in terms of Tc removal in $\mathrm{DIW}$. The $\mathrm{SnCl}_{2}$, which completely dissolved in solution, removed between $87 \%$ of the Tc in the 5 ppm solution and $93 \%$ of the Tc in the $56 \mathrm{ppm}$ solution. The $\%$ Tc removed held near constant after $6 \mathrm{~d}$ of contact. The $\mathrm{pH}$ of the solutions containing the $\mathrm{SnCl}_{2}$ was measured to be $1.56 \pm 0.04$. This acidic environment produced by the $\mathrm{SnCl}_{2}$ may hinder Tc(VII) reduction as the standard potential for Tc(VII) reduction increases with decreasing $\mathrm{pH}$, based on the $\mathrm{E}$ vs $\mathrm{pH}$ diagram. [28] However, the $\mathrm{Sn}$ (II) is likely stable in its reduced $\mathrm{Sn}$ (II) state in the acidic environment, which in turn could assist in Tc reduction.[29] In general, the Sn-A had a slower removal of Tc over the first $2 \mathrm{~d}$ compared to the $\mathrm{SnCl}_{2}$, removing between $87 \%-90 \%$ of the Tc at $2 \mathrm{~d}$ contact. At $4 \mathrm{~d}$ contact, the Sn-A had removed $>99.99 \%$ of the Tc in all three solutions. The $\mathrm{pH}$ of the Sn-A containing solutions was $7.87 \pm 0.08$. The DIW spiked with Tc and no $\mathrm{Sn}-\mathrm{A}$ or $\mathrm{SnCl}_{2}$ had a $\mathrm{pH}$ of $8.70 \pm 0.03$.

The Sn(II) present in solution is likely responsible for the removal of Tc observed. Figure 1(b) displays a measure of Tc removal effectiveness comparing the $\mathrm{Sn}-\mathrm{A}$ and $\mathrm{SnCl}_{2}$ in terms of mol Tc removed per $\mathrm{g}$ of $\mathrm{Sn}$ in the DIW experiments. In the $5 \mathrm{ppm}$ solutions the $\mathrm{SnCl}_{2}$ removed $0.007 \mathrm{~mol} \mathrm{Tc} / \mathrm{g} \mathrm{Sn}$ while the $\mathrm{Sn}-\mathrm{A}$ removed $0.048 \mathrm{~mol} \mathrm{Tc} / \mathrm{g} \mathrm{Sn}$; in the $28 \mathrm{ppm} \mathrm{Tc}$ solutions the $\mathrm{SnCl}_{2}$ removed $0.040 \mathrm{~mol} \mathrm{Tc/g} \mathrm{Sn}$ and the $\mathrm{Sn}-\mathrm{A}$ removed $0.260 \mathrm{~mol} \mathrm{Tc} / \mathrm{g} \mathrm{Sn}$; in the $56 \mathrm{ppm}$ Tc solution the $\mathrm{SnCl}_{2}$ removed $0.080 \mathrm{~mol} \mathrm{Tc} / \mathrm{g} \mathrm{Sn}$ while the $\mathrm{Sn}-\mathrm{A}$ removed $0.528 \mathrm{~mol} \mathrm{Tc} / \mathrm{g} \mathrm{Sn}$. This comparison highlights the improved performance of the Sn-A towards Tc removal compared with $\mathrm{SnCl}_{2}$, despite the $\mathrm{SnCl}_{2}$ containing a higher amount of $\mathrm{Sn}(\mathrm{II})$. The solid surface present in the Sn-A likely contributed to this improved Tc removal behaviour, possibly through facilitating electron transfer or aiding in bringing the Tc in close proximity to 
the reductant through a sorption process. Similar observations have been made for Fe(II) facilitated reduction of $\mathrm{Tc}$, where changing the substrate bearing the $\mathrm{Fe}$ (II) led to improved Tc removal,[30] and sorption of Fe(II) to a solid surface increased Tc removal.[31]

The mechanism of removal via $\mathrm{SnCl}_{2}$ is likely an aqeous phase reduction:

$$
3 \mathrm{Sn}^{2+}{ }_{(\mathrm{aq})}+2 \mathrm{TcO}_{4}^{-}{ }_{(\mathrm{aq})}+8 \mathrm{H}_{(\mathrm{aq})}^{+} \rightarrow 3 \mathrm{Sn}^{4+}{ }_{(\mathrm{aq})}+2 \mathrm{TcO}_{2(\mathrm{~s})}+4 \mathrm{H}_{2} \mathrm{O}_{(\mathrm{l})}
$$

Whereas on Sn-A, a two step process is more likely involving sorption of Tc on the apatite surface:

$$
\mathrm{TcO}_{4_{(a q}^{-}}^{-}+\mathrm{Sn}(\mathrm{II})-\mathrm{A}_{(\mathrm{s})} \rightarrow \mathrm{TcO}_{4_{(\text {(ads })}^{-}}+\mathrm{Sn}(\mathrm{IV})-\mathrm{A}
$$

Followed by a subsequent reduction of Tc:

$$
3 \mathrm{Sn}(\mathrm{II})-\mathrm{A}+\mathrm{TcO}_{4(\mathrm{ads})} \rightarrow \mathrm{TcO}_{2} \cdot \mathrm{xH}_{2} \mathrm{O}_{(\mathrm{s})}+\mathrm{Sn}(\mathrm{IV})-\mathrm{A}
$$

$\mathrm{SnCl}_{2}$ showed little additional removal of Tc after the intial contact time in all three concentrations of Tc in DIW. Two situations accounting for this beahviour are plausible:

1) following the intial removal of Tc, the lower amount of Tc in solution decreases the likelihood of a collision between $\mathrm{Sn}^{2+}{ }_{(\mathrm{aq})}$ and $\mathrm{TcO}_{4}{ }^{-}$that is required to facilitate the electron transfer for the redox process, [32] or 2) $\mathrm{Sn}^{2+}{ }_{(\mathrm{aq})}$ slowly oxidizes (due to residual $\mathrm{O}_{2}$ in the anaeobic chamber) in the aqueous solution, thus limiting the amount of reductant in solution. [29] A similar trend to situation 1 has been reported for the reduction of $\mathrm{Tc}(\mathrm{VII})$ using $\mathrm{Fe}(\mathrm{II})$, in which the solution phase reduction was kinetically hindered compared with the reduction occuring on a solid surface.[9] In Sn-A experiments, the fastest relative rates of removal occurred following a two day incubation period after which the Sn-A became more effective. As evidenced in Figure 1 by the higher level of Tc removal by the Sn-A compared with the $\mathrm{SnCl}_{2}$, an influence of the $\mathrm{Sn}-\mathrm{A}$ solid surface on the removal of Tc was present, likely caused by sorption of the $\mathrm{TcO}_{4}{ }^{-}$to the apatite, where it could then be reduced by the $\mathrm{Sn}(\mathrm{II})$. If a sorption step is occurring, it is possible 
that the nature of the supporting anions in the Sn-A structure may influence the rate of sorption, however this cannot be determined from the work here within. This behaviour is further evidenced by Sn-A exhibiting higher Tc removal despite having a lower Sn content.

\subsection{Characterization of Sn-A Following DIW Exposure}

The reacted Sn-A was removed from the $56 \mathrm{ppm}$ Tc DIW solution following the batch experiment and used for solid state characterization. The $56 \mathrm{ppm}$ Tc DIW experiment solid material was chosen to ensure sufficient presence of Tc on the Sn-A for analysis. At the time of collecting the $\mathrm{Sn}-\mathrm{A}$, the Tc concentration in solution was $1.4 \mathrm{ppb}$, as almost all the Tc was then present on the $1 \mathrm{~g}$ of $\mathrm{Sn}-\mathrm{A}$. Due to its solubility, no solids could be recovered from the $\mathrm{SnCl}_{2}$ batch experiments. Figure 2 (a) shows an SEM micrograph of the Sn-A following the batch experiment in DIW with 56 ppm Tc. XEDS spot analysis was used on points on the Sn-A structure, labelled (I) and (II) with arrows, and the resulting spectra are shown in Figure 2(b) and 2(c). A homogeneous distribution of Tc on the surface of the Sn-A is confirmed in both XEDS spectra, along with strong signals for $\mathrm{Sn}, \mathrm{Ca}$, and $\mathrm{P}$ from the Sn-A structure. Due to the excitation volume of the electron beam, the XEDS cannot distinguish if the Tc is present solely on the surface of the Sn-A or incorporated into the Sn-A structure.

The x-ray absorption near edge structure (XANES) spectrum collected from the Sn-A sample is shown in Figure 3(a). Three standard spectra were used to model the possible local environments for Tc: 1) $\mathrm{TcO}_{4}^{-}, 2$ ) Tc (IV) EDTA was used to model a Tc (IV) atom coordinated by oxygen atoms in a distorted octahedral environment, such as that expected for Tc(IV) sorbed to a mineral surface, and 3) $\mathrm{Tc}_{2} \mathrm{~S}_{7}$ was used to represent $\mathrm{Tc}(\mathrm{IV})$ coordinated by sulfide and disulfide ligands. The XANES spectrum obtained for Sn-A has a good fit with the exception at the top of the edge $(\sim 21070 \mathrm{eV})$. However, this did not affect the ability to determine sample 
composition from a linear combination fit. The fitting results, listed in Figure 3(c), show only one Tc species, Tc(IV) coordinated by oxygen atoms in a distorted octahedral manner. The slight mismatch at the top edge corresponds to a somewhat different local environment of Tc in this arrangement. While the contribution from $\mathrm{TcO}_{4}{ }^{-}$is approximately $5 \%$, the high $\mathrm{p}$ value of 0.123 means that the $\mathrm{TcO}_{4}{ }^{-}$signal is not meaningful.

Above the X-ray absorption edge, seen in Figure 3 (a), features were present that were utilized to probe the extended X-ray absorption fine structure (EXAFS) for the Sn-A sample. The resulting EXAFS spectrum is shown in Figure 3(b) and the corresponding fitting parameters in Figure 3(d). Further information on the fitting method can be found elsewhere.[33] Strong contribution to the spectrum from both $\mathrm{O}$ and Tc neighbours were confirmed by the low corresponding $\mathrm{p}$ values $(<0.001)$, and no improvement was observed upon shortening the Tc-O distance (as found in $\mathrm{TcO}_{4}{ }^{-}$). Although the spectrum is not identical to that of $\mathrm{TcO}_{2} \cdot 2 \mathrm{H}_{2} \mathrm{O}$, the Tc-O and Tc-Tc distances are similar to those of $\mathrm{TcO}_{2} \cdot 2 \mathrm{H}_{2} \mathrm{O}$, which is consistent with a surface precipitate similar in strcuture to $\mathrm{TcO}_{2} \bullet \mathrm{XH}_{2} \mathrm{O}$. There was no evidence of Tc-Sn interactions or Tc-Ca interactions. The combination of the SEM showing a Tc deposit on the Sn-A and XAS showing no incorporation into the apatite structure of the Sn-A strongly suggests that Sn-A functions through a surface mediated reduction (i.e., adsorption followed by reduction) of $\mathrm{Tc}(\mathrm{VII})$ to $\mathrm{Tc}(\mathrm{IV})$, which deposits evenly on the material surface as a surface precipitate. The mechanism prior to the reduction step is still to be determined; however, as discussed previously, an initial sorption to the apatite is likely based on results obtained from solution analysis in the batch experiments.

\subsection{Tc Removal Performance in LAW Simulant}


The averaged behaviour of the $\mathrm{Sn}-\mathrm{A}$ and $\mathrm{SnCl}_{2}$ in the $\mathrm{LAW}$ simulant is shown in Figure 4(a). The performance of both materials is lower in the LAW simulant. Both the Sn-A and $\mathrm{SnCl}_{2}$ experienced a large decrease to $<20 \%$ Tc removal by the $\mathrm{Sn}-\mathrm{A}$ after $14 \mathrm{~d}$ contact and $<15 \%$ Tc removal by the $\mathrm{SnCl}_{2}$ at a $1 \mathrm{~g}$ to $100 \mathrm{~mL}$ ratio. This decreased performance towards Tc removal may be a result of interference by other species in the LAW simulant on the redox processes of $\mathrm{Sn}-\mathrm{A}$ and $\mathrm{SnCl}_{2}$. The two materials rely on the reducing capacity of $\mathrm{Sn}(\mathrm{II})$, and if other oxidants are present, such as in the LAW simulant, they may be reduced in place of the Tc(VII). As was in the DIW experiments, the solid surface of the Sn-A provided an improvement over $\mathrm{SnCl}_{2}$ in the LAW simulant when the mol Tc removed per $\mathrm{g}$ of $\mathrm{Sn}$ is compared, Figure 4(b). The $\mathrm{Sn}-\mathrm{A}$ removed a maximum of $0.130 \mathrm{~mol} \mathrm{Tc} / \mathrm{g} \mathrm{Sn}$ and the $\mathrm{SnCl}_{2}$ removed $0.019 \mathrm{~mol} \mathrm{Tc/g} \mathrm{Sn.}$

Following the batch experiments in the LAW simulant, the $\mathrm{Sn}-\mathrm{A}$ was removed for further analysis to identify the possible interfering species. The surface of the Sn-A can be seen in the SEM micrograph, Figure 5(a). The Sn-A surface appears to be covered in a smoother desposit than the Sn-A surface following exposure to DIW, Figure 2(a). XEDS analysis of two spots, labeled I and II, show high levels of $\mathrm{Na}$ from the solution, along with signals for $\mathrm{Al}$ and $\mathrm{Cr}$ in both spots, Figure 5(b) and 5(c). The Al likely is present from incomplete washing following the experiment. $\mathrm{Cr}(\mathrm{VI})$ is a stronger oxidant than $\mathrm{Tc}(\mathrm{VII})$, was present in a much higher amount in the LAW simulant (1800 ppm Cr to $56 \mathrm{ppm} \mathrm{Tc)} \mathrm{and} \mathrm{may} \mathrm{be} \mathrm{interfering} \mathrm{with} \mathrm{the} \mathrm{performance} \mathrm{of}$ the Sn-A (it may get reduced to $\mathrm{Cr}$ (III) and precipate in $\mathrm{Cr}$ (III)-bearing solid phases). This makes Cr likely to interfere with the Tc reducing ability of the Sn-A, and led to its deposition on the Sn-A surface.

\subsection{Competition Between Cr and Tc}


The marked decrease in Tc removal by the Sn-A in the LAW simulant can be further understood through batch testing using the altered simulant compositions from Table 1, "LAW

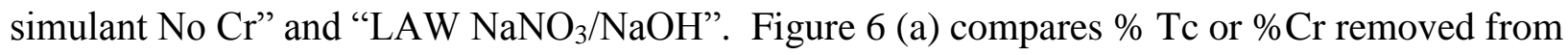
batch experiments performed with the LAW solutions using Sn-A at a $1 \mathrm{~g}: 100 \mathrm{~mL}$ ratio. As discussed in the previous section, the lowest performance by Sn-A was in the removal of Tc in the LAW simulant, with $<20 \%$ Tc removed. However, upon exposure of Sn-A to the "LAW simulant No Cr" containing 56 ppm Tc, a $59 \%$ removal of Tc was observed at $3 \mathrm{~d}$ and increased to $78 \%$ Tc removed at $14 \mathrm{~d}$. While lower than the Tc removal levels observed in DIW, it is confirmation that $\mathrm{Cr}(\mathrm{VI})$ interferes with the removal of Tc from the LAW simulant. In measurements of Tc removal from the "LAW NaNO $3 / \mathrm{NaOH}$ " spiked with $56 \mathrm{ppm}$ Tc, $79 \%$ Tc removal was observed after $3 \mathrm{~d}$ and increased slightly to $82 \% \mathrm{Tc}$ removal at $14 \mathrm{~d}$ contact. The absence of $\mathrm{Cr}(\mathrm{VI})$ from the LAW simulant, and the absence of other species in the LAW simulant, facilitated an increase in Tc removal, yet not to the levels observed in DIW. The similar Tc removal by Sn-A observed in the "LAW simulant No Cr" and "LAW NaNO $3 / \mathrm{NaOH}$ solutions suggests that the high alkalinity of the LAW simulant also affects removal of Tc by Sn-A. These results also suggest that the other metallic species (Al, Ni, Cd) and other ions $\left(\mathrm{SO}_{4}{ }^{2-}, \mathrm{NO}_{2}{ }^{-}\right.$etc. $)$in the LAW simulant solution have little effect on the removal of Tc. For comparison, the removal of $\mathrm{Cr}(\mathrm{VI})$ from the "LAW $\mathrm{NaNO}_{3} / \mathrm{NaOH}$ " solution spiked with 23 ppm $\mathrm{Cr}(\mathrm{VI})$, equivalent on a molar basis to $56 \mathrm{ppm} \mathrm{Tc}$, was studied and the results are also presented in Figure 6 (a). The Sn-A was able to remove $>98 \%$ of the Cr from the "LAW $\mathrm{NaNO}_{3} / \mathrm{NaOH}$ ". This result shows $\mathrm{Sn}-\mathrm{A}$ to be effective in the removal of $\mathrm{Cr}$ in the highly alkaline simulant environment, yet slightly hindered towards Tc removal. No changes in the 
levels of $\mathrm{Cr}$ can be quantified in the LAW simulant from Figure 4(a) due to the high initial $\mathrm{Cr}$ concentration (1800 ppm).

Based on the findings of Figure 6(a), potential affinity for $\mathrm{Cr}(\mathrm{VI})$ removal over $\mathrm{Tc}(\mathrm{VII})$ by Sn-A was investigated through batch experiments with $\mathrm{Tc}$ and $\mathrm{Cr}$ added in equimolar amount to solution. The solution used was the "LAW simulant No Cr" with initial concentrations of $53 \mathrm{ppm} \mathrm{Tc}(\mathrm{VII})$ and $28 \mathrm{ppm} \mathrm{Cr}(\mathrm{VI})$ spiked in the solution (equivalent to $0.5 \mathrm{mM}$ concentrations of each) containing Sn-A at at $1 \mathrm{~g}: 100 \mathrm{~mL}$ ratio. The intial stages of removal were of interest so sampling intervals were much shorter. The resulting behaviour is shown in Figure 6(b). In the intial stages of contact $(<6 \mathrm{~h})$ there was little difference in the removal of $\mathrm{Cr}$ and Tc. After $6 \mathrm{~h}, \mathrm{Cr}$ was removed to a much higher degree than Tc. At $48 \mathrm{~h}$, the Cr concentration had dropped to $0.06 \mathrm{mmol} / \mathrm{L}$ while the Tc had only lowered to $0.28 \mathrm{mmol} / \mathrm{L}$; at $288 \mathrm{~h}$ the concentration of $\mathrm{Cr}$ was $0.01 \mathrm{mmol} / \mathrm{L}$ and $0.15 \mathrm{mmol} / \mathrm{L} \mathrm{Tc}$. This result confirms what was seen in the "LAW $\mathrm{NaNO}_{3} / \mathrm{NaOH}$ " environment (Figure 6(a)) with Cr being removed with a higher efficiency than $\mathrm{Tc}$. This preference for $\mathrm{Cr}(\mathrm{VI})$ reduction may result from the more positive reduction potential for $\mathrm{Cr}(\mathrm{VI})_{2} \mathrm{O}_{7}{ }^{2-}$ of $1.33 \mathrm{~V}$ compared with $0.78 \mathrm{~V}$ for $\mathrm{Tc}(\mathrm{VII}) \mathrm{O}_{4}^{-}$.[34]

The high alkalinity of the LAW simulant also interferes with the Sn-A removal of Tc as increasing $\mathrm{pH}$ can alter how the $\mathrm{Sn}$-A structure is solubilized. To investigate this potenital interference, $1.0 \mathrm{~g}$ of Sn-A was placed in $100 \mathrm{~mL}$ of solutions of $\mathrm{pH}$ 7, $\mathrm{pH} 10$ and $\mathrm{pH} 13$ (DIW adjusted with $\mathrm{NaOH}$ ) and LAW simulant with and without Cr. Figure 7(a) shows the measured release of three species ( $\mathrm{Sn}, \mathrm{Ca}$ and $\mathrm{P}$ ) based on the ICP-MS analysis. Results show there is litte time dependence on elemental release as only slight changes were observed after $24 \mathrm{~h}$ of contact. The impact of $\mathrm{pH}$ on the dissolution of Sn-A is most evident in Figure 7 (b), which displays the average concentration of $\mathrm{Sn}, \mathrm{Ca}$ and $\mathrm{P}$ at $48 \mathrm{~h}-72 \mathrm{~h}$ at the different $\mathrm{pH}$ values. The $\mathrm{pH}$ of the 
LAW simulant was measured at 13.5. Sn was released in high amounts from the Sn-A as the pH is increased with a high dissolution of $\mathrm{Sn}$ in the LAW, Ca showed a lower release with increasing $\mathrm{pH}$, and $\mathrm{P}$ concentration in solution remained relatively constant. It should be noted that differences in $\mathrm{Ca}$ and $\mathrm{P}$ concentations could not be successfully measured in the LAW simulant solution due to the initial high concentrations in solution. As $\mathrm{pH}$ increased, more $\mathrm{Sn}$ is lost from the Sn-A solid, which could account for the decrease in performance toward Tc removal at increasing $\mathrm{pH}$. [22]

The initial batch experiments performed in LAW simulant were conducted at a ratio of $1 \mathrm{~g}: 100 \mathrm{~mL}$. However, identification of $\mathrm{Cr}(\mathrm{VI})$ as an interfering species that is preferrably reduced over Tc(VII) by Sn-A suggests that the redox active $\mathrm{Sn}(\mathrm{II})$ in the $\mathrm{Sn}-\mathrm{A}$ may not have been present in sufficient amount to reduce the Tc. Two additional batch experiments were performed using increased solid : solution ratios for the Sn-A in LAW simulant. The Sn-A had a reduction capacity ranging from $1210 \mu \mathrm{eq} / \mathrm{g}$ to $3460 \mu \mathrm{eq} / \mathrm{g}$ using the $\mathrm{Ce}(\mathrm{IV})$ method. The reduction capacity measures the number of mols of available electrons available for redox (eq) per gram of material. The variance in the reduction capacity between batches of Sn-A resulted from the age of the material and its exposure to open atmosphere, both factors decreasing the reduction capacity.

Figure 8 displays the $\%$ Tc removed by the Sn-A in LAW simulant at increased solid : solution ratios. In LAW simulant batch experiments in Figure 4, the Sn-A was added at $7 \times$ the Tc content (at $56 \mathrm{ppm}$ ) based on the $1200 \mu \mathrm{eq} / \mathrm{g}$ reduction capacity of the Sn-A batch used, which lead to a maximum $18.0 \%$ Tc removal after $14 \mathrm{~d}$. Sn-A was next tested by adding a sufficient amount to reduce all of the $\mathrm{Cr}(\mathrm{VI})$ and $\mathrm{Tc}(\mathrm{VII})$ in the LAW simulant based on the reduction capacity of $1200 \mu \mathrm{eq} / \mathrm{g}$ for the batch used, and an averaged maxima of $27.5 \%$ of the 
Tc was removed after $24 \mathrm{~h}$. This result reaffirms that the high alkalinity of LAW interferes with Sn-A and not solely the presence of $\mathrm{Cr}(\mathrm{VI})$. Increasing the $\mathrm{Sn}-\mathrm{A}$ amount to remove $3 \times$ the $\mathrm{Cr}(\mathrm{VI})$ content and $10 \times$ the Tc content, based on the $3460 \mu \mathrm{eq} / \mathrm{g}$ reduction capacity of the batch used, resulted in a $65 \%$ removal of Tc after $24 \mathrm{~h}$. The higher Sn-A loading amount batch experiments were performed in aerobic conditions. This does not influence Sn-A removal of Tc based on DIW Tc removal; see supplemental information Figure S1. By increasing the amount of Sn-A in the LAW simulant, significant amounts of Tc can be removed, although the relationship between Tc removal and Sn-A mass is not linear.

\section{DISCUSSION}

${ }^{99} \mathrm{Tc}$ is a component of concern in nuclear wastes owing to its long half life, high environmental mobility due to its anionic speciation as pertechnetate in aerobic environments, and challenges to its incorporation in mid- to high-temperature waste forms. Sequestering Tc from aqueous nuclear wastes can be achieved by materials that are capable of sorbing or reducing Tc. Sn-A was found to have high Tc removal capability, with $>99.99 \%$ removal achieved in $<96 \mathrm{~h}$ in neutral $\mathrm{pH}$ conditions. This level of removal is on par with or better,than other successful Tc removal technologies in weak ionic strength, near neutral solutions when compared with the reported Tc distribution coefficients, $\mathrm{K}_{d}(\mathrm{in} \mathrm{mL} / \mathrm{g}) . \mathrm{K}_{\mathrm{d}}$ is calculated commonly as follows:

$$
K_{d}=\frac{c_{i, b l a n k}-c_{i}}{c_{i}} \times \frac{V_{s}}{m_{g}}
$$

Where $c_{i, \text { blank }}$ is the initial concentration of the species or of the blank solution, $c_{i}$ is the concentration of the species at a specific interval, $V_{s}$ is the volume of solution in $\mathrm{mL}$, and $m_{g}$ is the mass of the material added to solution in $\mathrm{g}$. It should be noted that $\mathrm{K}_{\mathrm{d}}$ calculated for $\mathrm{Tc}$ in such a sense is representative of the amount of Tc present in solution relative to the amount 
removed from solution. Traditional calculation of $\mathrm{K}_{\mathrm{d}}$ gives the ratio of a species present in aqueous vs. solid state.

$\mathrm{A} \mathrm{Sb}-\mathrm{SnO}_{2}$ material was reported in near neutral ionic strength systems to give Tc distribution coefficients, $\mathrm{K}_{\mathrm{d}}$ (in $\mathrm{mL} / \mathrm{g}$ ), of $1 \times 10^{6} \mathrm{~mL} / \mathrm{g}$; [35] nanoiron on commercially available silicone in a DIW system gave a Tc $\mathrm{K}_{\mathrm{d}}$ of $8100 \mathrm{~mL} / \mathrm{g}$;[36] Purolite A5320E resin in a near neutral groundwater brine measured a Tc $\mathrm{K}_{\mathrm{d}}$ of $1.2 \times 10^{3} \mathrm{~mL} / \mathrm{g} ;[14]$ nanoporous Sn-phosporous measured a Tc $\mathrm{K}_{\mathrm{d}}$ of $9 \times 10^{4} \mathrm{~mL} / \mathrm{g} ;[37]$ activated carbon $824 \mathrm{BC}$ in artificial groundwater gave a Tc $\mathrm{K}_{\mathrm{d}}$ of $120 \mathrm{~mL} / \mathrm{g}$;[18] calcium apatite in artificial groundwater measured a Tc $\mathrm{K}_{\mathrm{d}}$ of 223 $\mathrm{mL} / \mathrm{g} ;[18]$ granual activated carbon in different groundwater gave a Tc $\mathrm{K}_{\mathrm{d}}$ of $2.4 \times 10^{4} \mathrm{~mL} / \mathrm{g}$;[38] a macroporous poly(GMA-co-EGDMA) polymer in near neutral solutions measured a Tc $\mathrm{K}_{\mathrm{d}}$ of $2.3 \times 10^{3} \mathrm{~mL} / \mathrm{g}$.[39] In comparison, the Sn-A in DIW in this study measured a Tc $\mathrm{K}_{\mathrm{d}}$ of $3.7 \times 10^{7}$ $\mathrm{mL} / \mathrm{g}$ confirming its strong performance as a Tc removal material from near neutral, low ionic strength environments. The Sn-A can function to remove Tc(VII) in both anaerobic and oxic environments based on the results shown in Figure S1 and Figure 8. This is an added benefit for any eventual field applications.

In a LAW solution, simulating the tank waste present at the Hanford site, the Tc removal capacity of Sn-A was decreased, as was similarily observed for supported zerovalent iron when moving from neutral $\mathrm{pH}$ solutions to a LAW environment.[36] This decrease by the Sn-A was the result of two factors: 1) the high alkalinity of the LAW solution leading to increased release of Sn from the Sn-A, and 2) competition with $\mathrm{Cr}(\mathrm{VI})$, which is kinetically favoured, for the reduction of Tc. This issue can be overcome through increasing the amount of Sn-A in the LAW. 
A possible application of the Tc removal ability of $\mathrm{Sn}-\mathrm{A}$ is in the fabrication of low temperature cementitious waste forms (such as Cast Stone at the Hanford Site and Saltstone at Savannah River site). [40, 41] Cast Stone and Saltstone are comprised of blast furnace slag, fly ash and ordinary Portland cement. The current end of life destination for Hanford Site immobilized low-activity waste (ILAW) and solidified secondary wastes is disposal at the Integrated Disposal Facility (IDF) on the Hanford Site. Previous performance and risk assessments to evaluate any potential impact resulting from the disposal of various solidified LAW waste forms have shown that release rates from non-glass waste forms may not be sufficiently low over long durations to meet drinking water standards. Preliminary leaching experiments (up to $91 \mathrm{~d}$ duration) on Cast Stone monoliths containing different LAW and secondary waste simulants have provided promising Tc release rates,[26, 42] although the short term measurements do not account for any potential long term release of Tc due to exposure to the dissolved oxygen in vadose zone pore water and susceptibility of Tc(IV) species to reoxidation.[43] Therefore an opportunity exists for improved retention of Tc within cementitious waste forms. One possibility for improving the long term retention of radionuclides in cementitious waste forms is through the incorporation of "getters", such as Sn-A, into the waste form formulation. A getter would reduce $\mathrm{Tc}(\mathrm{VII})$ in the waste stream to $\mathrm{Tc}(\mathrm{IV})$, as shown in this work, prior to inclusion in the waste form, and then provide a stable matrix that would limit re-oxidation and release of Tc. Presence of Sn-A in such a waste form may also lower Tc leaching rates as the apatite of the Sn-A has an affinity for Tc, and can sorb any prematurely released $\mathrm{Tc}\left(\right.$ as $\mathrm{Tc}(\mathrm{VII}) \mathrm{O}_{4}{ }^{-}$), and facilitate its reduction to an immobile $\mathrm{Tc}(\mathrm{IV})$ form. While a higher amount of Sn-A was required for significant Tc removal from the LAW simulant, such an increase would not sigficantly impact the composition of a cementitious waste form. If Sn-A 
were to be added at a $10 \mathrm{~g}: 100 \mathrm{~mL}$ ratio to the LAW, this would only account for $\sim 3 \mathrm{wt} \%$ of the total mass of the waste form, based on the 0.55 free water to dry mix recipe commonly used for Cast Stone.[26] Future work will expand on what is presented here, and include incorporation of Sn-A as a Tc-getter within Cast Stone in lab scale leach testing to further test its capability as a getter for Tc in terms of Tc desorption, long term stability and compatibility with Cast Stone.

\section{CONCLUSIONS}

$\mathrm{Sn}(\mathrm{II})$-apatite (Sn-A) was investigated for the removal of Tc(VII) from aqueous environments. In DI water, high levels of Tc removal (> $99.99 \%)$ were observed after $4 \mathrm{~d}$ contact with the $\mathrm{Sn}-\mathrm{A}$. Compared with $\mathrm{SnCl}_{2}$ this higher removal is attributed to the presence of a solid interface on the Sn-A facilitating the reduction of Tc(VII) to Tc(VI). In LAW simulant, the Tc removal ability of the Sn-A was decreased due to the alkalinty of the LAW simulant and a preference for the reduction of $\mathrm{Cr}(\mathrm{VI})$ over Tc(VII) by the Sn-A. However, increasing the amount of Sn-A added to the LAW simulant led to appreciable amounts of Tc removal. Sn-A can thus be considered as a candidate Tc-getter to be included in cementitious waste form testing.

\section{Acknowledgements}

This work was completed as part of the Supplemental Immobilization of Hanford Low-Activity Waste project with Washington River Protection Solutions (WRPS). Support for this project came from the U.S. Department of Energy's Office of Environment Management. The authors wish to thank David Swanberg of WRPS for continued support, the analytical staff in the Environmental Sciences Lab at PNNL and the staff at the Environmental Molecular Sciences Lab (EMSL) at PNNL. The authors thank Jim Duncan of RJ Lee group in Pasco, WA for 
supplying the Sn-Apatite. Portions of this work (WWL) were supported by the U.S. Department of Energy, Office of Science, Basic Energy Sciences, Chemical Sciences, Biosciences, and Geosciences Division (CSGB). The Heavy Element Chemistry Program was performed at Lawrence Berkeley National Laboratory under contract No. DE-AC02-05CH11231. Tc K-edge XAFS spectra were obtained at the Stanford Synchrotron Radiation Lightsource, SLAC National Accelerator Laboratory, which is supported by the U.S. Department of Energy, Office of Science, Office of Basic Energy Sciences under Contract No. DE-AC02-76SF00515.

\section{REFERENCES}

[1] G. Desmet and C. Myttenaere, Technetium in the Environment, Springer Science \& Business Media, Place, Published, 1986

[2] K. Shi, X. Hou, P. Roos and W. Wu, Determination of technetium-99 in environmental samples: A review, Analytica Chimica Acta 709 (2012) 1-20

[3] S. B. Jenkinson, D. McCubbin, P. H. W. Kennedy, A. Dewar, R. Bonfield and K. S. Leonard, An estimate of the inventory of technetium-99 in the sub-tidal sediments of the Irish Sea, Journal of Environmental Radioactivity 133 (2014) 40-47

[4] K. Tagami, Technetium-99 Behavior in the Terrestrial Environment

Field Observations and Radiotracer Experiments, Journal of Nuclear and Radiochemical Sciences 4 (2003) A1-A8

[5] R. E. Gephart, A short history of waste management at the Hanford Site, Physics and Chemistry of the Earth, Parts A/B/C 35 (2010) 298-306

[6] A. A. Kruger and D. S. Kim, Technetium Incorporation in Glass for the Hanford Tank Waste Treatment and Immobilization Plant, Place, Published,2015

[7] J. M. Zachara, J. Serne, M. Freshley, F. Mann, F. Anderson, M. Wood, T. Jones and D. Myers, Geochemical Processes Controlling Migration of Tank Wastes in Hanford's Vadose Zone, Vadose Zone Journal 6 (2007) 985-1003

[8] R. E. Meyer, W. D. Arnold and F. I. Case, The Solubility of Electrodeposited Tc(IV) Oxides, ORNL-6374 Oak Ridge National Laboratory, Oak Ridge, Tennessee (1987)

[9] D. Cui and T. E. Eriksen, Reduction of pertechnetate by ferrous iron in solution: Influence of sorbed and precipitated Fe (II), Environmental science \& technology 30 (1996) 2259-2262 [10] S. V. Mattigod, R. J. Serne and G. E. Fryxell, Selection and Testing of "Getters" for Adsorption of Iodine-129 and Technetium-99: A Review, PNNL-14208 Pacific Northwest National Laboratory, Richland, Washington (2003)

[11] E. M. Pierce, S. V. Mattigod, R. J. Serne, J. P. Icenhower, R. D. Scheele, W. Um, N. Qafoku and J. H. Westsik, Review of Potential Candiate Stabilization Technologies for Liquid and Solid Secondary Waste Streams, PNNL-19122 Pacific Northwest National Laboratory, Richland, Washington (2010) 
[12] B. Gu, G. M. Brown, P. V. Bonnesen, L. Liang, B. A. Moyer, R. Ober and S. D. Alexandratos, Development of novel bifunctional anion-exchange resins with improved selectivity for pertechnetate sorption from contaminated groundwater, Environmental science \& technology 34 (2000) 1075-1080

[13] W. Um, H.-S. Chang, J. P. Icenhower, W. W. Lukens, R. J. Serne, N. P. Qafoku, J. H. Westsik Jr, E. C. Buck and S. C. Smith, Immobilization of 99-technetium (VII) by Fe (II)goethite and limited reoxidation, Environmental science \& technology 45 (2011) 4904-4913 [14] J. B. Duncan, G. A. Cooke and L. L. Lockrem, Assessment of Technetium Leachability in Cement Stabilized Basin 43 Groundwater Brine, RPP-RPT-29195 (2009)

[15] R. C. H. Moore, K.C.; Zhao, H.; Hasan, A.; Hasan, M.; Bontchev, R.; Salas, F.; Lucero, D., Anionic Sorbents for Arsenic and Technetium Species, SAND2003-3360 (2003)

[16] T. Gajda, P. Sipos and H. Gamsjäger, The standard electrode potential of the Sn4+/Sn2+ couple revisited, Monatsh Chem 140 (2009) 1293-1303

[17] E. Deutsch, R. C. Elder, B. A. Lange, M. J. Vaal and D. G. Lay, Structural characterization of a bridged 99Tc-Sn-dimethylglyoxime complex: implications for the chemistry of 99mTcradiopharmaceuticals prepared by the Sn (II) reduction of pertechnetate, Proceedings of the National Academy of Sciences 73 (1976) 4287-4289

[18] D. Li, D. I. Kaplan, A. S. Knox, K. P. Crapse and D. P. Diprete, Aqueous 99Tc, 129I and 137Cs removal from contaminated groundwater and sediments using highly effective low-cost sorbents, Journal of Environmental Radioactivity 136 (2014) 56-63

[19] Y. Okamoto, Accumulation of technetium-99m methylene diphosphonate: Conditions affecting adsorption to hydroxyapatite, Oral Surgery, Oral Medicine, Oral Pathology, Oral Radiology, and Endodontology 80 (1995) 115-119

[20] S. Toegel, O. Hoffmann, W. Wadsak, D. Ettlinger, L.-K. Mien, K. Wiesner, J. Nguemo, H.

Viernstein, K. Kletter, R. Dudczak and M. Mitterhauser, Uptake of bone-seekers is solely associated with mineralisation! A study with 99mTc-MDP, 153Sm-EDTMP and 18F-fluoride on osteoblasts, Eur J Nucl Med Mol Imaging 33 (2006) 491-494

[21] M. Duc, G. Lefevre, M. Fedoroff, J. Jeanjean, J. C. Rouchaud, F. Monteil-Rivera, J. Dumonceau and S. Milonjic, Sorption of selenium anionic species on apatites and iron oxides from aqueous solutions, Journal of Environmental Radioactivity 70 (2003) 61-72

[22] J. B. Duncan, K. Hagerty, W. P. Moore, R. N. Rhodes, J. M. Johnson and R. C. Moore, Laboratory Report on the Reduction and Stabilization (Immobilization) of Pertechnetate to Technetium Dioxide using Tin(II)apatite, LAB-RPT-12-00001 Washington River Protection Solutions (2012)

[23] D. McConnell and D. W. Foreman, The properties and structure of Ca 10 (PO 4 ) 6 (OH) 2 ; its relation to tin (II) apatite, The Canadian Mineralogist 8 (1966) 431-436

[24] N. Qafoku, J. J. Neeway, A. R. Lawter, T. G. Levitskaia, R. J. Serne, J. Westsik, J.H. and M. M. Valenta Snyder, Technetium and Iodine Getters to Improve Cast Stone Performance, PNNL-23282 Pacific Northwest National Laboratory (2014)

[25] W. Um, J.-S. Yang, R. J. Serne and J. H. Westsik, Reductive capacity measurement of waste forms for secondary radioactive wastes, Journal of Nuclear Materials 467, Part 1 (2015) 251-259 [26] J. H. Westsik, G. F. Piepel, M. J. Lindberg, P. G. Heasler, T. M. Mercier, R. L. Russel, A. D. Cozzi, W. E. Daniel, R. E. Eibling, E. K. Hansen, M. R. Reigal and D. J. Swanberg, Supplemental Immobilization of Hanford Low-Activity Waste: Cast Stone Screening Tests, PNNL-22747, SRNL-STI-2013-00465 Rev. 0, Pacific Northwest National Laboratory, Richland, Washington and Savannah River National Laboratory, Aiken, South Carolina (2013) 
[27] P. J. Certa and P. A. Empey, River Protection Project System Plan, ORP-11242 Revision 6, Washington River Protection Solutions, LLC, Richland, Washington (2011)

[28] R. E. Wildung, S. W. Li, C. J. Murray, K. M. Krupka, Y. Xie, N. J. Hess and E. E. Roden, Technetium reduction in sediments of a shallow aquifer exhibiting dissimilatory iron reduction potential, FEMS Microbiology Ecology 49 (2004) 151-162

[29] P. Marcel and M. Pourbaix, Atlas of electrochemical equilibria in aqueous solutions, Houston, Tex. : National Association of Corrosion Engineers, Place, Published,1974

[30] T. Peretyazhko, J. M. Zachara, S. M. Heald, B. H. Jeon, R. K. Kukkadapu, C. Liu, D. Moore and C. T. Resch, Heterogeneous reduction of Tc(VII) by Fe(II) at the solid-water interface, Geochimica et Cosmochimica Acta 72 (2008) 1521-1539

[31] J. M. Zachara, S. M. Heald, B.-H. Jeon, R. K. Kukkadapu, C. Liu, J. P. McKinley, A. C. Dohnalkova and D. A. Moore, Reduction of pertechnetate [Tc(VII)] by aqueous Fe(II) and the nature of solid phase redox products, Geochimica et Cosmochimica Acta 71 (2007) 2137-2157 [32] R. A. Marcus, On the Theory of Oxidation-Reduction Reactions Involving Electron Transfer. I, The Journal of Chemical Physics 24 (1956) 966-978

[33] W. W. Lukens, J. J. Bucher, N. M. Edelstein and D. K. Shuh, Products of Pertechnetate Radiolysis in Highly Alkaline Solution: Structure of TcO2 $\times \mathrm{HH} 2 \mathrm{O}$, Environmental Science \& Technology 36 (2002) 1124-1129

[34] W. M. Haynes, CRC handbook of chemistry and physics, CRC press, Place, Published,2014 [35] R. Koivula and R. Harjula, Selective Sorption of Technetium on Antimony-Doped Tin Dioxide, Separation Science and Technology 46 (2010) 315-320

[36] J. G. Darab, A. B. Amonette, D. S. D. Burke, R. D. Orr, S. M. Ponder, B. Schrick, T. E. Mallouk, W. W. Lukens, D. L. Caulder and D. K. Shuh, Removal of Pertechnetate from Simulated Nuclear Waste Streams Using Supported Zerovalent Iron, Chemistry of Materials 19 (2007) 5703-5713

[37] D. M. Wellman, S. V. Mattigod, K. E. Parker, S. M. Heald, C. Wang and G. E. Fryxell, Synthesis of Organically Templated Nanoporous Tin(II/IV) Phosphate for Radionuclide and Metal Sequestration, Inorganic Chemistry 45 (2006) 2382-2384

[38] B. Gu, K. E. Dowlen, L. Liang and J. L. Clausen, Efficient separation and recovery of technetium-99 from contaminated groundwater, Separations Technology 6 (1996) 123-132 [39] R. V. Hercigonja, D. D. Maksin, A. B. Nastasović, S. S. Trifunović, P. B. Glodić and A. E. Onjia, Adsorptive removal of technetium-99 using macroporous poly(GMA-co-EGDMA) modified with diethylene triamine, Journal of Applied Polymer Science 123 (2012) 1273-1282 [40] S. K. Sundaram, K. E. Parker, M. M. Valenta, S. G. Pitman, J. Chun, C. W. Chung, M. L. Kimura, C. A. Burns, W. Um and J. H. Westsik Jr., Secondary Waste Form Development and Optimization - Cast Stone, PNNL-20159 Rev. 1, Pacific Northwest National Laboratory, Richland, Washington (2011)

[41] J. Westsik Jr, K. J. Cantrell, R. J. Serne and N. Qafoku, Techne-tium Immobilization Forms Literature Survey, PNNL-23329, EMSP-RPT-023 (Richland, WA: Pacific Northwest National Laboratory, 2014) (2014)

[42] R. J. Serne and J. H. Westsik Jr., Data Package for Secondary Waste Form Down-SelectionCast Stone, PNNL-20706 Pacific Northwest National Laboratory, Richland, Washington (2011) [43] D. Fan, R. P. Anitori, B. M. Tebo, P. G. Tratnyek, J. S. Lezama Pacheco, R. K. Kukkadapu, L. Kovarik, M. H. Engelhard and M. E. Bowden, Oxidative Remobilization of Technetium Sequestered by Sulfide-Transformed Nano Zerovalent Iron, Environmental science \& technology 48 (2014) 7409-7417 
TOC/Abstract Art

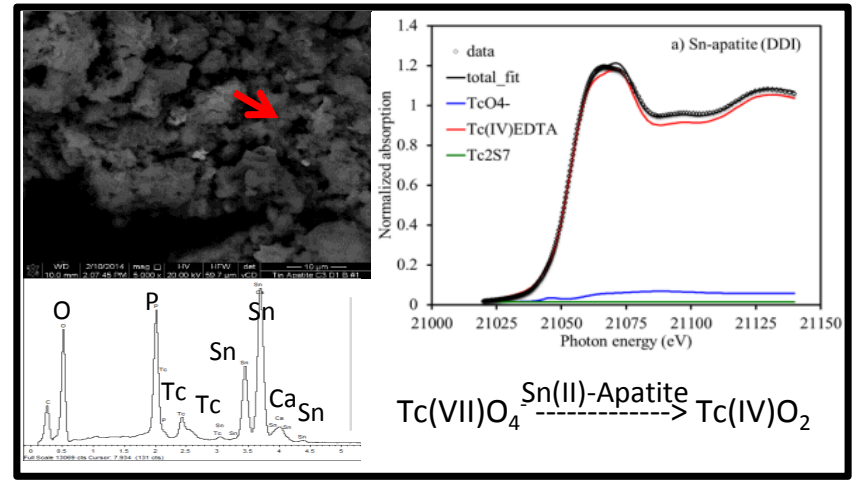




\section{Captions}

Table 1 - Composition of the three variants of the LAW simulant solution used in this study

Figure 1 - a) \% Tc removed as a function of time by $\mathrm{Sn}-\mathrm{A}$ and $\mathrm{SnCl}_{2}$ in $\mathrm{DIW}$ at $\mathrm{Tc} \approx 5 \mathrm{ppm}$, $28 \mathrm{ppm}$ and $56 \mathrm{ppm}$, b) comparison of Tc removal, in mol, based on the Sn content of the $\mathrm{Sn}-\mathrm{A}$ and $\mathrm{SnCl}_{2}$, in $\mathrm{g}$, over time. The two materials were added at a $1 \mathrm{~g}: 100 \mathrm{~mL}$ solution ratio.

Figure 2 - a) SEM micrograph of the Sn-A following exposure at $56 \mathrm{ppm}$ Tc in DIW and the corresponding XEDS spectra from the spots labelled b) I and c) II

Figure 3 - a) XANES spectrum collected from the Sn-A following exposure in 56 ppm Tc DIW with fit from c) and b) EXAFS spectrum collected from the Sn-A following exposure in DIW, and the resulting fit from data in $\mathrm{d}$ ). The numbers in parentheses represent the standard deviations of the contribution of that component for the ending digit, $p$ is the probability that improvement of the fit, when this standard is included, is due to random error. $S_{0}^{2}=0.9 *$ fixed), $\Delta E=4(1) \mathrm{eV}$ for the fit

Figure 4 - a) \% Tc removed as a function of time by $\mathrm{Sn}-\mathrm{A}$ and $\mathrm{SnCl}_{2}$ in $\mathrm{LAW}$ simulant at $\mathrm{Tc} \approx 5 \mathrm{ppm}, 28 \mathrm{ppm}$ and $56 \mathrm{ppm}$. b) comparison of Tc removal, in mol, based on the Sn content of the $\mathrm{Sn}-\mathrm{A}$ and $\mathrm{SnCl}_{2}$, in $\mathrm{g}$, over time. The two materials were added at a $1 \mathrm{g:} 100$ mL solution ratio.

Figure 5 - a) SEM micrograph of the Sn-A getter following exposure at 56 ppm Tc in LAW simulant and the corresponding XEDS spectra from the spots labelled b) I and c) II.

Figure 6 - a) \% removal values for Tc removal with Sn-A in LAW simulant with 53 ppm Tc and 1800 ppm Cr (black), LAW simulant No Cr with 53 ppm Tc and 0 ppm Cr (red), $\mathrm{LAW} \mathrm{NaNO} / \mathrm{NaOH}_{3}$ with $53 \mathrm{ppm} \mathrm{Tc}$ (green) and $\mathrm{Cr}$ removal from the $\mathrm{LAW} \mathrm{NaNO}_{3} / \mathrm{NaOH}$ with $28 \mathrm{ppm} \mathrm{Cr}$ (blue). b) Change in concentration for $\mathrm{Tc}$ and $\mathrm{Cr}$ following contact with Sn-A in "LAW simulant No Cr" spiked with $\mathrm{Tc}=53 \mathrm{ppm}$ and $\mathrm{Cr}=28 \mathrm{ppm}$ (equivalent to $0.5 \mathrm{mM}$ each).

Figure 7 - Following placing $1 \mathrm{~g}$ of $\mathrm{Sn}-\mathrm{A}$ in $100 \mathrm{~mL}$ of DIW at various pH (adjusted with $\mathrm{NaOH}$ ) and $\mathrm{LAW}$ simulant a) change in concentration of $\mathrm{Sn}$ and $\mathrm{P}$ over exposure time and b) comparison of the release of $\mathrm{Sn}, \mathrm{P}$ and $\mathrm{Ca}$ as a function of $\mathrm{pH}$

Figure 8 - removal of Tc by Sn-A in LAW simulant in varying amounts of Sn-A added based on the reduction capacity of the Sn-A. The 7X Tc(VII) content and $1 \mathrm{X} \mathrm{Cr}(\mathrm{VI})+10 \mathrm{X}$ Tc(VII) content batch experiments used Sn-A with a reduction capacity of $1200 \mu \mathrm{eq} / \mathrm{g}$ and the $3 X \mathrm{Cr}(\mathrm{VI})+10 \mathrm{X} \mathrm{Tc}(\mathrm{VII})$ experiment used Sn-A with a $3460 \mu \mathrm{eq} / \mathrm{g}$ reduction capacity. 


\begin{tabular}{|l|c|c|c|}
\hline \multirow{2}{*}{ Compound } & \multicolumn{3}{|c|}{ Amount (g/L) } \\
\cline { 2 - 4 } & $\begin{array}{l}\text { LAW } \\
\text { Simulant }\end{array}$ & $\begin{array}{c}\text { LAW } \\
\text { Simulant } \\
\text { No Cr }\end{array}$ & $\begin{array}{c}\text { LAW } \\
\text { NaNO }\end{array}$ /NaOH \\
\hline $\mathrm{KNO}_{3}$ & 5.17 & 5.17 & 0 \\
\hline $\mathrm{NaCl}$ & 3.85 & 3.85 & 0 \\
\hline $\mathrm{NaF}$ & 2.07 & 2.07 & 0 \\
\hline $\mathrm{Na}_{2} \mathrm{SO}_{4}$ & 18.95 & 18.95 & 0 \\
\hline $\mathrm{NaOH}(50 \%$ sol'n) & 347.81 & 347.81 & 347.81 \\
\hline $\left.\mathrm{Al}_{(\mathrm{NO}}\right)_{3} \cdot 9 \mathrm{H}_{2} \mathrm{O}$ & 179.54 & 179.54 & 0 \\
\hline $\mathrm{Na}_{3} \mathrm{PO}_{4} \cdot 12 \mathrm{H}_{2} \mathrm{O}$ & 29.18 & 29.18 & 0 \\
\hline $\mathrm{NaC}_{2} \mathrm{H}_{3} \mathrm{O}_{2}$ & 4.91 & 4.91 & 0 \\
\hline $\mathrm{Na}_{2} \mathrm{CO}_{3}$ & 45.33 & 45.33 & 0 \\
\hline $\mathrm{NaCr}_{2} \mathrm{O}_{7} \cdot 2 \mathrm{H}_{2} \mathrm{O}$ & 4.96 & 0 & 0 \\
\hline $\mathrm{NaNO}_{2}$ & 60.80 & 60.80 & 0 \\
\hline $\mathrm{NaNO}_{3}$ & 88.70 & 88.70 & 88.70 \\
\hline $\mathrm{Pb}\left(\mathrm{NO}_{3}\right)_{2}$ & 0.13 & 0.13 & 0 \\
\hline $\mathrm{Ni}_{\left(\mathrm{NO}_{3}\right)_{2} \cdot 6 \mathrm{H}_{2} \mathrm{O}}$ & 1.49 & 1.49 & 0 \\
\hline $\mathrm{Cd}\left(\mathrm{NO}_{3}\right)_{2} \cdot 4 \mathrm{H}_{2} \mathrm{O}$ & 0.08 & 0.08 & 0 \\
\hline
\end{tabular}

Table 1 

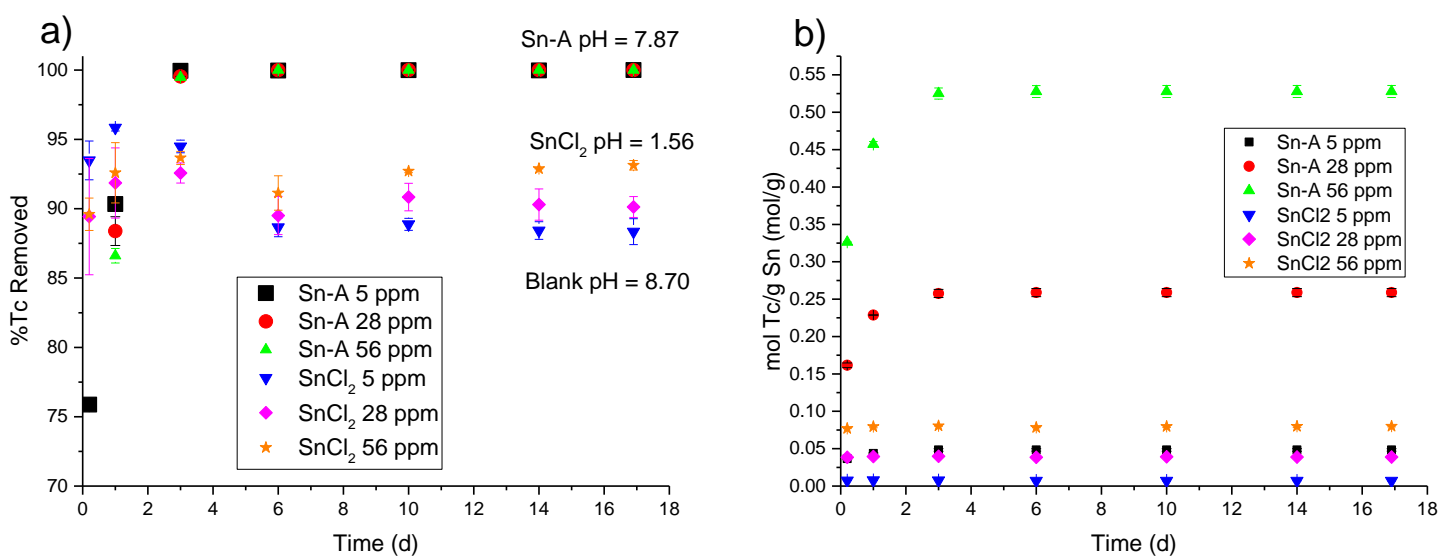

Figure 1 


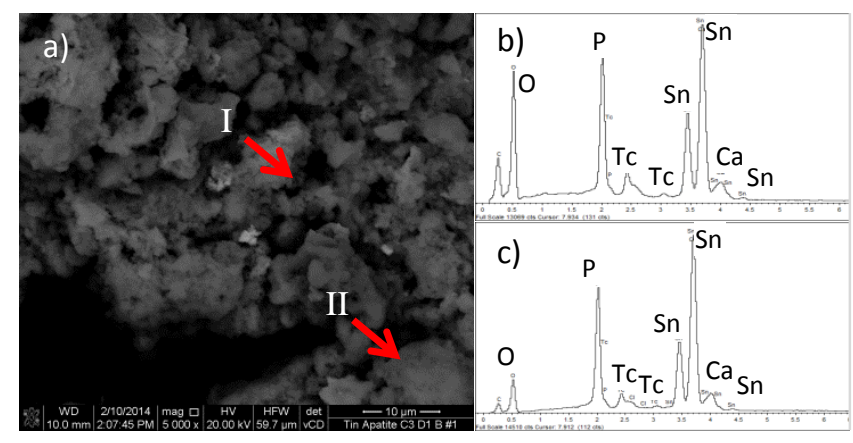

Figure 2 
b)

a)
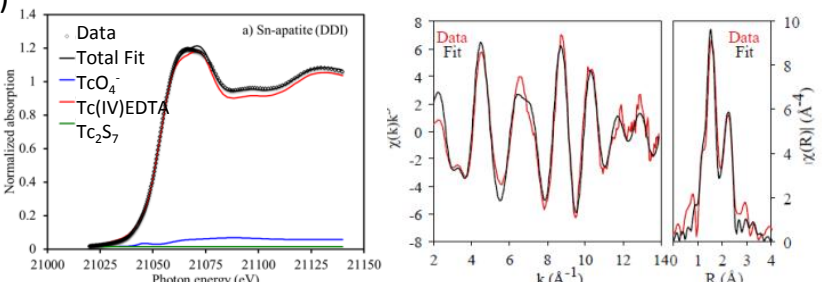

c)

\begin{tabular}{cccccc|}
$\mathrm{TcO}_{4}^{-}$ & $\mathbf{p}$ & $\mathbf{T c}(\mathbf{I V})$ EDTA & $\mathbf{p}$ & $\mathrm{Te}_{2} \mathrm{~S}_{7}$ & $\mathbf{p}$ \\
\hline $0.05(3)$ & 0.123 & $0.95(4)$ & $<0.001$ & $0.00(7)$ & 1 \\
\hline
\end{tabular}

d)

\begin{tabular}{|ccccc|}
\hline $\begin{array}{c}\# \text { of } \\
\text { Neighbours }\end{array}$ & $\begin{array}{c}\text { Distance } \\
(\AA)\end{array}$ & $\mathbf{\sigma}^{2}\left(\AA^{2}\right)$ & $\mathbf{p}$ & $\mathbf{T c O}_{2}-2 \mathbf{H}_{2} \mathbf{O}$ \\
\hline $\mathrm{O}=6$ & $2.031(7)$ & $0.0055(6)$ & $<0.001$ & $4 \mathrm{O}$ at $2.02 \AA$ \\
\hline $\mathrm{Tc}=2$ & $2.556(7)$ & $0.0063(5)$ & $<0.001$ & $2 \mathrm{Tc}$ at $2.57 \AA$ \\
\hline
\end{tabular}

Figure 3 
a)

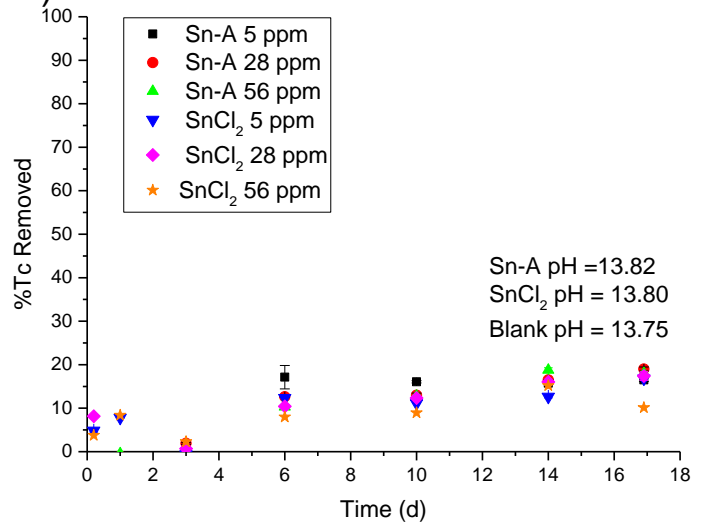

b)

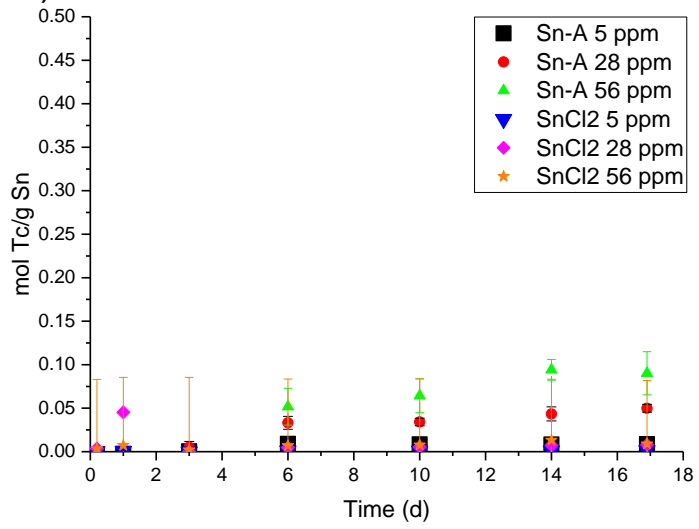

Figure 4 

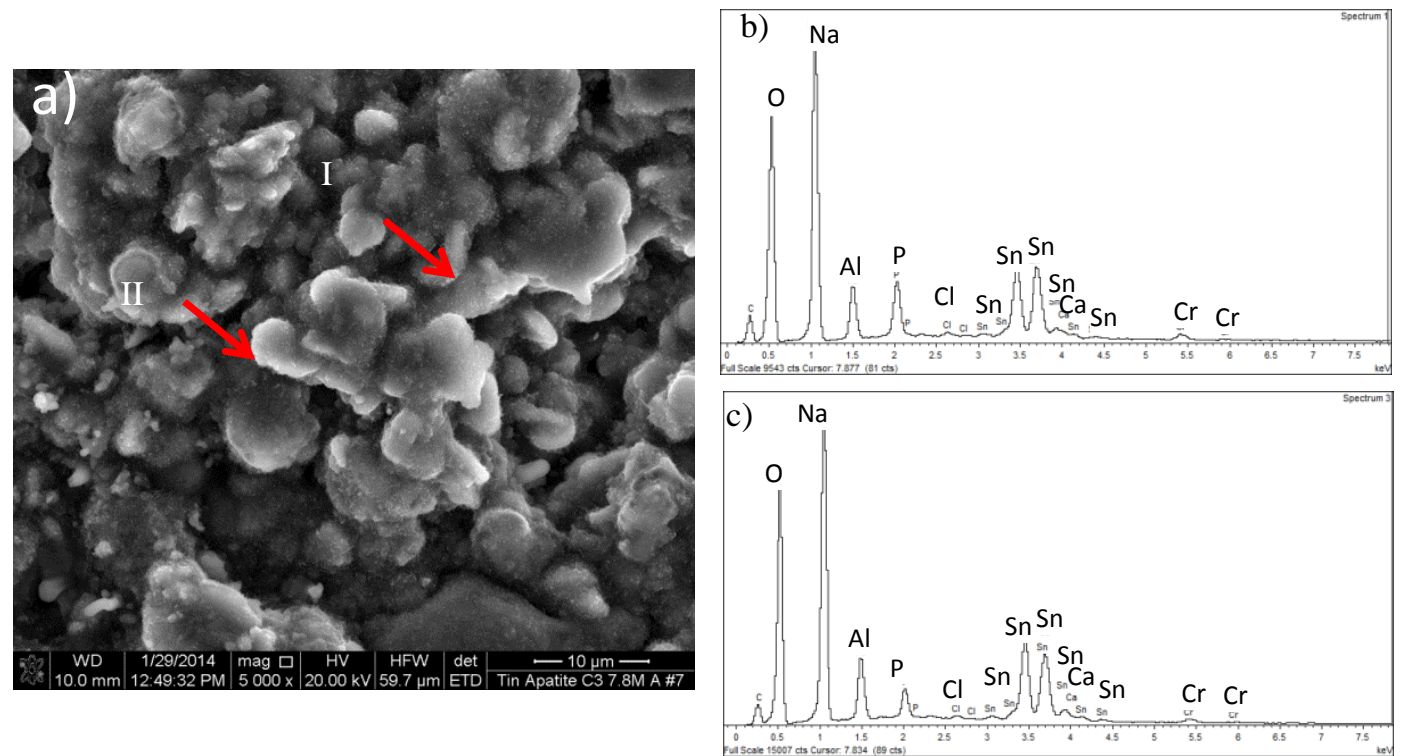

Figure 5 


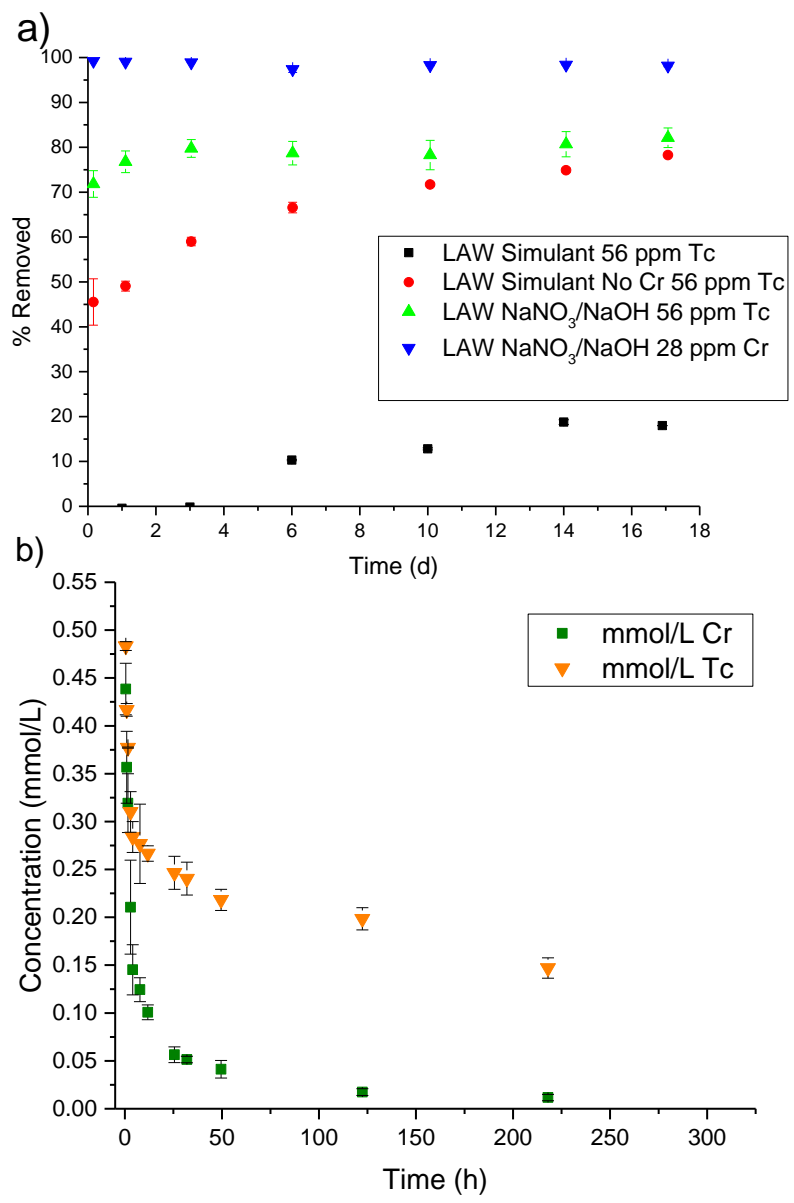

Figure 6 

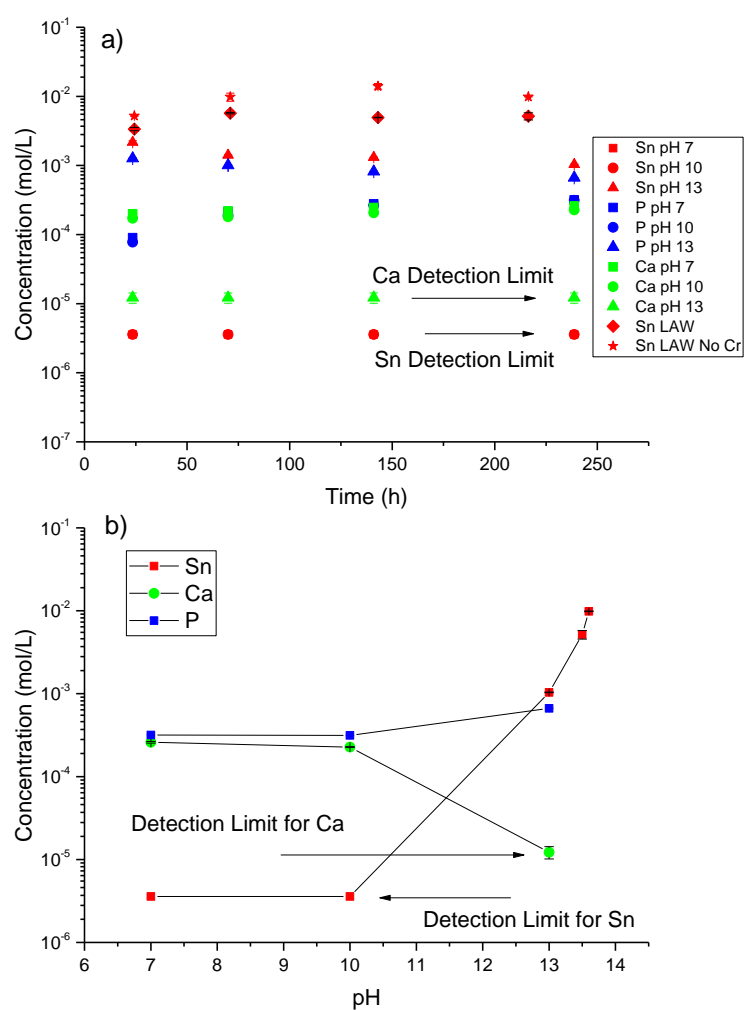

Figure 7 


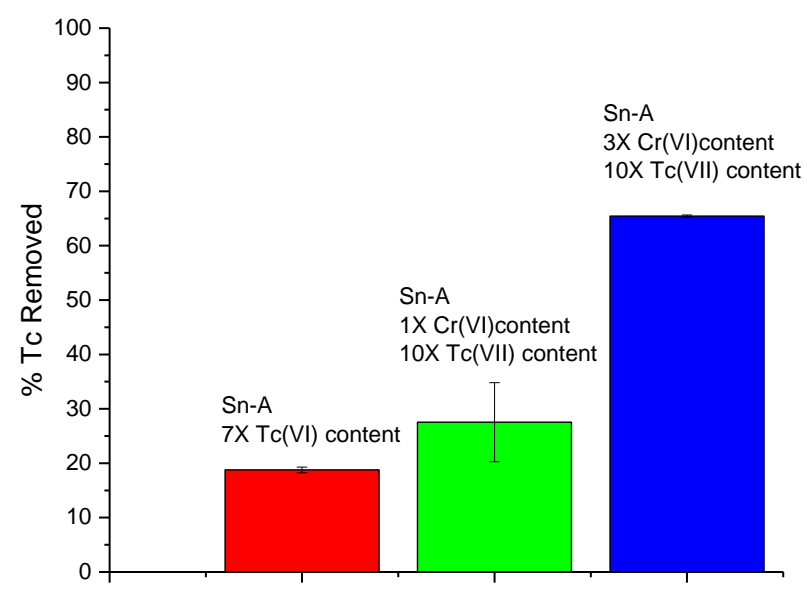

Figure 8 